\title{
Rectovaginal Examination, Transvaginal Ultrasonography, and Magnetic Resonance Imaging as Diagnostic Tools for Identifying Deep Infiltrating Endometriosis Nodules
}

\author{
Rectovaginal Toucher, Ultrasonografi Transvaginal dan Magnetic Resonance \\ Imaging sebagai Modalitas Penunjang Diagnosa Nodul \\ Endometriosis Susukan Dalam
}

\author{
Florencia Wirawan, Luky S Marwali, Refni Muslim, Eva R Silalahi, Harjo S Bayuaji, Astri Anindita \\ Endometriosis Center Fatmawati Central General Hospital \\ Jakarta
}

\begin{abstract}
Objective: To investigate the comparison between rectovaginal examination (RVT), transvaginal ultrasonography (TVUS) and magnetic resonance imaging (MRI) as diagnostic tools for identifying various Deep Infiltrating Endometriosis (DIE).

Methods: Prospective longitudinal study was done involving 31 women referred for surgical management of DIE. Calculation of sensitivity, specificity, positive predictive value (PPV), negative predictive value (NPV), and accuracy of RVT, TVUS and MRI for DIE were recorded.

Results: The mean age was 35.1 years. DIE were present in $95.45 \%$ of women which commonly located at uterosacral ligaments $(58.33 \%)$, followed by rectovaginal $(16,67 \%)$, rectosigmoid-colon $(16.67 \%)$ and bladder-ureter $(8.3 \%)$. TVUS had the best accuracy (RVT $50.24 \%$; TVUS $88.85 \%$; MRI $75.77 \%$ ) among other diagnostic tools for nodules located at uterosacral ligaments (RVT 52.63\%; TVUS 87\%; MRI 40\%) and rectovaginal (RVT 76.75\%; TVUS 93.34\%; MRI 80\%), but it poorly identified nodules located at rectosigmoid (RVT 20\%; TVUS 65.56\%; MRI 88.75\%) and bladder-ureteral area (RVT 50.44\%; TVUS 87.66\%; MRI 93.55\%). RVT had good PPV $(88.89 \%)$ but bad NPV (32.01\%) profile, made it worth to be a screening diagnostic tool.

Conclusion: RVT was a good screening diagnostic tools as it could be done easily but was weak in diagnosing anterior DIE. TVUS gave a better diagnosis rates on DIE located at sacrouterina ligaments and rectovaginal area whereas MRI did better on bowel DIE (rectosigmoid-colon area) and urological DIE (bladder-ureteral area).

[Indones J Obstet Gynecol 2018; 6-3: 167-171]

Keywords: deep infiltrating endometriosis, magnetic resonance imaging, tranvaginal ultrasonography
\end{abstract}

\begin{abstract}
Abstrak
Tujuan: Untuk mengetahui perbandingan rectovaginal toucher (RVT), USG transvaginal dan MRI sebagai penunjang diagnosis dalam mengidentifikasi Endometriosis Susukan Dalam (ESD).

Metode: Sebuah studi prospektif longitudinal dengan 33 perempuan terlibat, perempuan dijadwalkan untuk menerima tindakan operasi untuk ESD. Sensitivitas, spesifisitas, nilai prediksi positif dan negatif serta akurasi dari RVT, USG dan MRI dinilai.

Hasil: Rerata usia adalah 35,1 tahun. ESD ditemukan pada 95,45\% perempuan, paling sering pada uterosacral ligaments $(58,33 \%)$, disusul oleh rectovagina (16,67\%), rectosigmoid-kolon $(16,67 \%)$ dan bladder-ureter (8,3\%). USG memiliki tingkat akurasi terbaik (RVT 50,24\%; TVUS 88,85\%; MRI 75,77\%) dibandingkan modalitas diagnosa lainnya untuk nodul pada ligamentum uterosakral (RVT 52,63\%; TVUS 87\%; MRI 40\%) dan rektovagina RVT 76,75\%; TVUS 93,34\%; MRI 80\%), tetapi kurang baik dalam mendiagnosa nodul di rektosigmoid (RVT 20\%; TVUS 65,56\%; MRI 88,75\%) dan area kandung kemih-ureter (RVT 50,44\%; TVUS 87,66\%; MRI 93,55\%). RVT memiliki nilai prediksi positif yang baik $(88,89 \%)$ namun nilai prediksi negatif yang rendah (32,01\%), RVT dapat digunakan sebagai skreening a wal diagnosa ESD.
\end{abstract}

Kesimpulan: RVT dapat digunakan sebagai alat diagnosa awal karena dapat dilakukan secara mudah namun lemah dalam mendiagnosa ESD anterior. USG memberi gambaran yang baik dalam mendiagnosa ESD pada lokasi sakrouterina dan rektovagina, sedangkan MRI baik dalam mendiagnosa nodul endometriosis rektosigmoid dan kandung kemih-ureter.

[Maj Obstet Ginekol Indones 2018; 6-3: 167-171]

Kata kunci: endometriosis susukan dalam, magnetic resonance imaging, transvaginal ultrasonography

Correspondence: Florencia Wirawan.florencia.wirawan@gmail.com

\section{INTRODUCTION}

Deep Infiltrating Endometriosis (DIE) was a benign disease marked by the ectopic presence of endometrium deeper than $5 \mathrm{~mm}$ beneath the peritoneal surface, that infiltrated different pelvic location whether anteriorly or posteriorly. ${ }^{1}$ It could be located anywhere including uterosacral ligaments, vagina, intestine, bladder or even ureter. As the DIE nodules were a major contribution to pain symptom for deep infiltrating endometriosis patients, radical surgical resection was the mainstay of treatment for this form of endometriosis. A proper diagnostic tools should be used in order to map the exact location of DIE 
nodule, so in the time any surgical procedures occurred, all remaining nodules could be resected and complication could be avoided. Magnetic resonance imaging (MRI) and Transvaginal sonography (TVS) had been recommended for diagnosing and locating DIE. Bazot, et al $^{1-3}$ found that MRI provided a more reliable map of DIE than physical examination or TVS, but TVS and physical examination should remain the first-line technique examination, although normal finding did not rule out the diagnosis. In this study, we wanted to compare these three modalities in diagnosing DIE in various location including their strength and weakness as a consideration of their usage.

\section{METHODS}

Prospective longitudinal study was done on tertiary gynecology unit. Study was done by involving 31 women referred for surgical management of DIE between November 2015 until January 2017. All women underwent RVT and TVUS with/without additional MRI examination. Diagnostic criteria for RVT was identification of endometriotic nodules on palpation, whereas for both TVUS and MRI was based on visualization of hypointense/hypoechoic areas in specific location. Calculation of sensitivity, specificity, positive pre-dictive value (PPV), negative predictive value (NPV), and accuracy of RVT, TVUS and MRI for DIE on various sites were then recorded, with surgical/histological finding as the golden standard.

\section{Rectovaginal Examination}

Deep Infiltrating Endometriosis was diagnosed in a state when lesions were visualized on the posterior vaginal fornix during speculum insertion; or a nodule was detected on vaginal palpation examination, involving the vagina, torus uterinus, uterosacral ligaments, or pouch of Douglas; and a mass or infiltration was detected on rectal digital examination, involving the rectosigmoid colon. ${ }^{1,2}$ All the examination were performed by experienced residents and gynecologist.

\section{Transvaginal Ultrasonography}

The TVS was performed with an GE Voluson E6 Ultrasound Machine. Each examination was interpreted directly by highly trained gynecologist sonographer with more than 10 years of experience in gynecologic imaging. DIE was diagnosed when a morphological criteria included abnormal hypoechoic linear thickening and nodules/masses with or without regular contours were found in at least one structure (uterosacral ligament, vagina, rectovaginal septum, rectosigmoid colon, or bladder). ${ }^{2-4}$

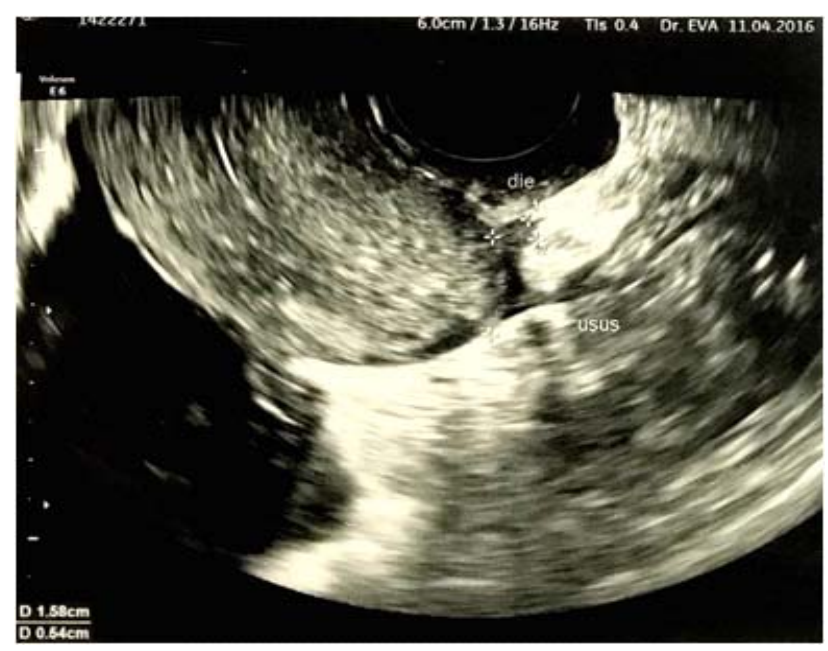

Figure 1. TVUS showed Deep Infiltrating Endometriosis infiltrated posteriorly until anterior rectum wall and rectovaginal

\section{Magnetic Resonance Imaging}

The MRI was done by opacification of the vagina and rectum with saline solution or sonographic jelly inside the vagina and the rectum to get better exposure of the anatomical space. No contrast was used. Each examination was interpreted by experienced radiologist. The diagnosis of DIE was based on the presence of morphologic abnormalities at posterior or anterior DIE sites. Uterosacral ligaments endometriosis was diag-nosed when a nodule was found at the site in a form of fibrotic thickening compared to the contralateral USL5. Rectovaginal septum endo-metriosis was diagnosed by a nodule passing through the lower border of the posterior cervix. Rectosigmoid colon endometriosis was diagnosed by diasapperance of the fat tissue plane and its replacement by a tissue mass. ${ }^{5}$ Bladder and ureter endometriosis was diagnosed by appearance of nodule foci at the anatomical sites. ${ }^{5}$ 


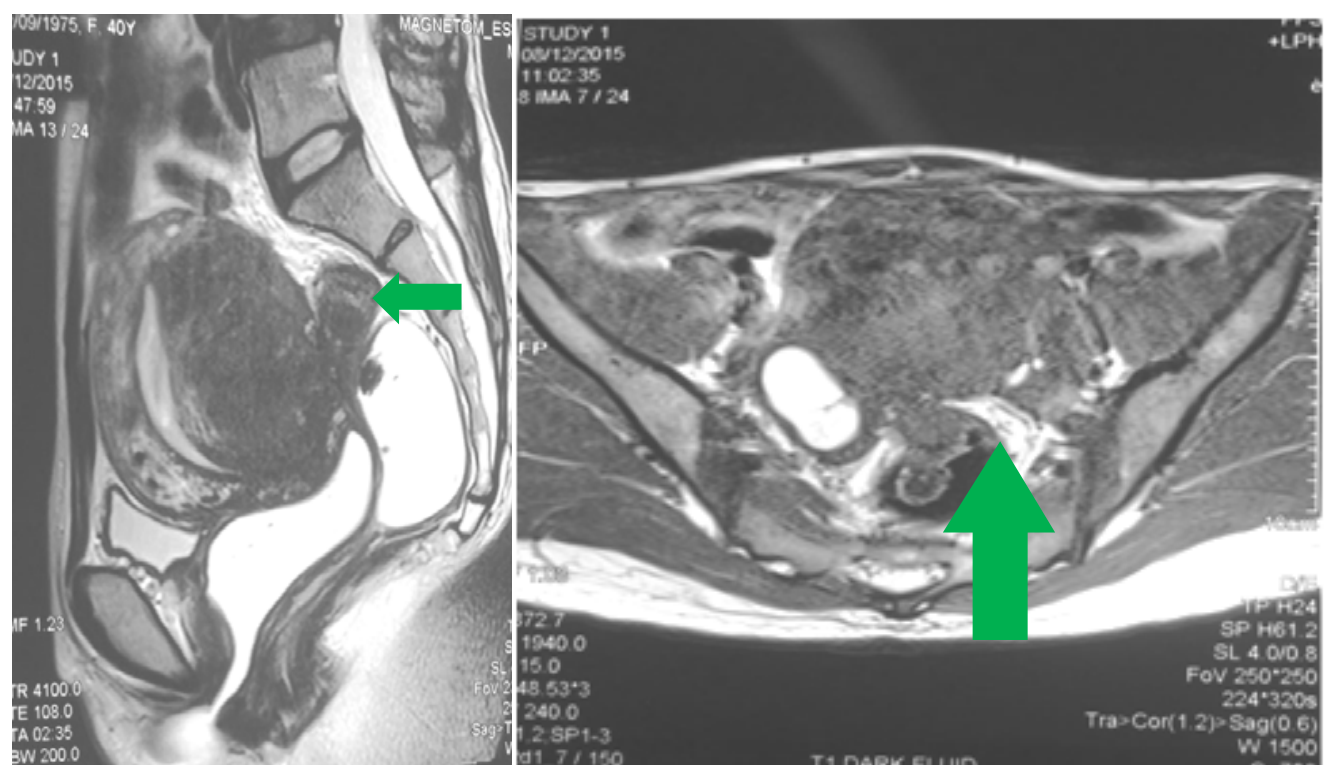

Figure 2. MRI showed adenomyosis in uterine posterior corpus, infiltrated posteriorly until anterior rectum wall into the lumen.

\section{Surgical/Histological Finding (reference standard)}

Laparoscopy was performed on every single patients include in this study. Surgical finding was based on masses visually found when the procedure occurred. All location of endometriosis were recorded on the surgical reports. Endometriosis was diagnosed histologically by the presence of ectopic endometrial tissue in a form of ectopic glands together with stroma. ${ }^{6}$

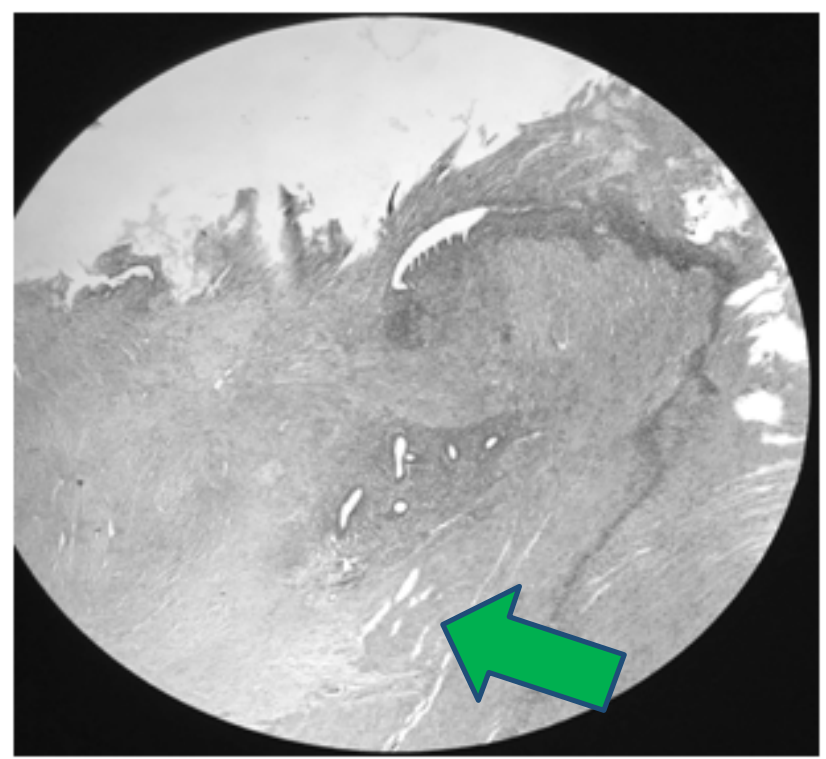

Figure 3. Histological finding of ectopic endometrial gland.

\section{Statical Analysis}

For each four location including uterosacral ligaments, rectovaginal, rectosigmoid and bladderureter were evaluated by comparing them with the standard reference (surgical/histological finding). The sensitivity, specificity, positive - negative predictive values, and accuracy of every modality were then recorded.

\section{RESULT}

The mean age of samples was 35.1 years. DIE distributed in different locations, but commonly found and uterosacral ligament (58.33\%), whether on one side or both; followed by rectovaginal and rectosigmoid area $(16.67 \%)$; lastly by bladder-ureter area $(8.3 \%)$. Firstly, the overall sensitivity, specificity, positive - negative predictive values, and accuracy of every modality were recorded. The overall sensitivity of RVT, TVUS, MRI were 45.71\%; $67.64 \% ; 52.63 \%$ respectively. The overall specificity of RVT, TVUS, MRI were 50.44\%; 88.03\%; $95.22 \%$ respectively. The overall positive predictive value of RVT, TVUS, MRI were $88.89 \%$; $88.46 \% ; 83.33 \%$ respectively. The overall negative predictive value of RVT, TVUS, MRI were $32.01 \%$; $78.88 \% ; 85.44 \%$ respectively. The overall accuracy of RVT, TVUS, MRI were 50.24\%; 88.85\%; 75.77\% respectively. Then, the sensitivity, specificity, PPV, NPV and accuracy on four location were recorded. Data can be seen on table 3 . 
Table 1. Distribution of DIE

\begin{tabular}{lcc}
\hline \hline \multirow{2}{*}{ Location } & \multicolumn{2}{c}{ Responses } \\
\cline { 2 - 3 } & $\mathbf{n}$ & Percent \\
\hline Uterosacral Ligament & 14 & 58.33 \\
Rectovaginal & 4 & 16.67 \\
Rectosigmoid Colon & 4 & 16.67 \\
Bladder - ureter & 2 & 8.3 \\
\hline \hline
\end{tabular}

Table 2. Overall Sensitivity, Specificity, PPV, NPV and Accuracy of RVT, TVUS and MRI

\begin{tabular}{lccc}
\hline \hline & $\begin{array}{c}\text { RVT } \\
\text { \% }\end{array}$ & $\begin{array}{c}\text { TVUS } \\
\text { \% }\end{array}$ & $\begin{array}{c}\text { MRI } \\
\text { \% }\end{array}$ \\
\hline Sensitivity & 45.71 & 67.64 & 52.63 \\
Specificity & 50.44 & 88.03 & 95.22 \\
PPV & 88.89 & 98.46 & 83.33 \\
NPV & 32.01 & 78.88 & 85.44 \\
Accuracy & 50.24 & 88.85 & 75.77 \\
\hline \hline
\end{tabular}

$(0 \%)$, which means that if there was no nodule palpated at RVT examination doesn't mean that there will be no Deep Infiltrating Endometriosis. Moreover RVT can only access around vaginal and rectum part, so diagnosing Deep Infiltrating Endometriosis located at urological sites was nearly impossible. Patient with typical symptoms such as, severe dysmenorrhea, dysuria, dyschezia and dyspareunia, further examination using other diagnostic methods could be considered.

Transvaginal Ultrasonography (TVUS) was a good modality available for diagnosing deep infiltrating endometriosis as it gave a wide exposure of gynecological anatomy. ${ }^{7-9}$ This study showed that for overall accuracy, TVUS still the best diagnostic methods (RVT 50.24\%; TVUS 88.85\%; MRI 75.77\%). But as study went deeper, it show that TVUS was great at diagnosing DIE nodules located at uterosacral ligaments

Table 3. Sensitivity, Specificity, PPV, NPV and Accuracy of RVT, TVUS and MRI on Various Location

\begin{tabular}{|c|c|c|c|c|c|c|}
\hline Location & Modality & $\begin{array}{c}\text { Sensitivity } \\
\%\end{array}$ & $\begin{array}{c}\text { Specificity } \\
\%\end{array}$ & $\begin{array}{c}\text { PPV } \\
\%\end{array}$ & $\begin{array}{c}\text { NPV } \\
\%\end{array}$ & $\underset{\%}{\text { Accuracy }}$ \\
\hline \multirow{3}{*}{ Uterosacral Ligaments } & RVT & 52.63 & 88 & 100 & 65 & 52.63 \\
\hline & TVUS & 73.68 & 99 & 93.33 & 90 & 87 \\
\hline & MRI & 33.33 & 35 & 100 & 55 & 40 \\
\hline \multirow{3}{*}{ Rectovaginal } & RVT & 55.55 & 80.01 & 71.42 & 76.75 & 76.75 \\
\hline & TVUS & 66.67 & 89.55 & 100 & 88.43 & 93.34 \\
\hline & MRI & 50 & 100 & 100 & 80 & 80 \\
\hline \multirow{3}{*}{ Rectosigmoid } & RVT & 20 & 90 & 100 & 90 & 20 \\
\hline & TVUS & 75 & 95 & 60 & 94 & 65.56 \\
\hline & MRI & 100 & 100 & 66.67 & 100 & 88.75 \\
\hline \multirow{3}{*}{ Bladder and Ureter } & RVT & 0 & 79.99 & 0 & 80.56 & 50.44 \\
\hline & TVUS & 33.3 & 88.87 & 44.5 & 92 & 87.66 \\
\hline & MRI & 50 & 97.77 & 100 & 95.55 & 93.55 \\
\hline
\end{tabular}

\section{DISCUSSION}

This study show that RVT, TVUS and MRI had their own roles in diagnosing Deep Infiltrating Endometriosis. RVT was a very simple examination that could be done easily in everyday practice. With high score of Positive Predictive Value (88.89\%), shows that if the nodule was palpable during RVT examination, the chance Deep Infiltrating Endometriosis mass was high, but on the other hand RVT shows a very low Negative Predictive Value
(RVT 52.63\%; TVUS 87\%; MRI 40\%) and rectovaginal. (RVT 76.75\%; TVUS 93.34\%; MRI 80\%), but lack of strength at diagnosing rectosigmoid (RVT 20\%; TVUS 65.56\%; MRI 88.75\%) and bladder-ureter DIE (RVT 50.44\%; TVUS $87.66 \%$; MRI 93.55\%). But still TVUS gave better perception of DIE than RVT itself.

As stated on the previous line, Magnetic Resonance Imaging (MRI) provided better diagnostic rates on bowel (RVT 20\%; TVUS 65.56\%; MRI 88.87\%) and urological (RVT 50.44\%; TVUS 
87.66\%; MRI 93.55\%) endometriosis. Bowel endometriosis was one of the most severe forms of DIE. ${ }^{1}$ With accurate preoperative diagnosis, mapping of the nodule could be done, and best procedure could be performed. It was also crucial for informing women on the specific risks of surgery for example colorectal resection. ${ }^{10}$ Various features of colorectal endometriosis can influence surgical management, such as the degree of rectal wall infiltration, the size of the rectal lesion, the distance from the anal margin and the possible association with other endometriotic lesions. ${ }^{10}$ Although urological endometriosis cases were rare, only for about $1-2 \%$ of all endometriosis cases, the side effects occurred were devastating. Silent hydronephrosis or even silent loss of kidney secondary to urological endometriosis could happen whether in a form of blocking mass or ureter stricture mimicry. ${ }^{11,12}$ MRI gave better mapping on both sites, providing better prognosis for bowel and urological DIE patients.

\section{CONCLUSION}

Early diagnosis of pelvic endometriosis, and especially DIE, even though was a major challenge, but it could help to avoid mutilating surgery, improved quality of life, and enhanced fertility. ${ }^{12}$ RVT should be done in daily examination on endometriosis patient but weak in diagnosing anterior DIE. TVUS gave a better diagnosis rates on DIE located at sacrouterine ligaments and rectovaginal area whereas MRI did better on bowel DIE (rectosigmoid-colon area) and urological DIE (bladder-ureteral area).

\section{REFERENCES}

1. Bazot M, Lafont C, Rouzier R, Roseau G, Thomassin-Naggara I, Darai E. Diagnostic accuracy of physical examination, transvaginal sonography, rectal endoscopic sonography, and magnetic resonance imaging to diagnose deep infiltrating endometriosis. Fertil Steril. 2008: 1-9.
2. Chapron C, Vieira M, Chopin N, Balleyguier C, Barakat H, Dumontier I, et al. Accuracy of rectal endoscopic ultrasonography and magnetic resonance imaging in the diagnosis of rectal involvement for patients pre- senting with deeply infiltrating endometriosis. Ultrasound Obstet Gynecol. 2004; 24: 175-9.

3. Bazot M, Malzy P, Cortez A, Roseau G, Amouyal P, Darai E. Accuracy of transvaginal sonography and rectal endoscopic sonography for the diagnosis of deep infiltrating endometriosis. Ultrasound Obstet Gynecol. 2007; 30: 994-1001.

4. Balleyguier C, Chapron C, Dubuisson JB, Kinkel K, Fauconnier $\mathrm{A}$, Vieira $\mathrm{M}$, et al. Comparison of magnetic resonance imaging and transvaginal ultrasonography in diagnosing bladder endometriosis. J Am Assoc Gynecol Laparosc. 2002; 9: 15-23.

5. Nishimura K, Togashi K, Itoh K, Fujisawa I, Noma S, Kawamura Y, et al. Endometrial cysts of the ovary: MR imaging. Radiol 1987; 162: 315-8.

6. Cornillie FJ, Oosterlynck D, Lauweryns JM, Koninckx PR. Deeply infiltrating pelvic endometriosis: histology and clinical significance. Fertil Steril. 1990; 53: 978-83.

7. Abrao MS, Goncalves MO, Dias JA Jr, Podgaec S, Chamie LP, Blasbalg R. Comparison between clinical examination, transvaginal sonography and magnetic resonance imaging for the diagnosis of deep endometriosis. Hum Reprod. 2007; 22: 3092-7.

8. Guerriero S, Ajossa S, Gerada M, D’Aquila M, Piras B, Melis GB. "Tenderness-guided" transvaginal ultrasonography: a new method for the detection of deep endometriosis in patients with chronic pelvic pain. Fertil? Steril. 2007; 88(5): 1293-7.

9. Bazot M, Bornier C, Dubernard G, Roseau G, Cortez A, Darai E. Accuracy of magnetic resonance imaging and rectal endoscopic sonography for the prediction of location of deep pelvic endometriosis. Hum Reprod. 2007; 22: 1457-63.

10. Chapron C, Dubuisson JB, Chopin N, Foulot H, Jacob S, Vieira $M$, et al. Deep pelvic endometriosis: management and proposal for a "surgical classification". Gynecol Obstet Fertil. 2003; 31: 197-206.

11. Takeuchi H, Kuwatsuru R, Kitade M, Sakurai A, Kikuchi I, Shimanuki $\mathrm{H}$, et al. A novel technique using magnetic resonance imaging jelly for evaluation of rectovaginal endometriosis. Fertil Steril 2005; 83: 442-7.

12. Darai E, Thomassin I, Barranger E, Detchev R, Cortez A, Houry S, et al. Feasibility and clinical outcome of laparoscopic colorectal resection for endometriosis. Am J Obstet Gynecol 2005; 192: 394-400.

13. Darai E, Marpeau O, Thomassin I, Dubernard G, Barranger E, Bazot M. Fertility after laparoscopic colorectal resection for endometriosis: preliminary results. Fertil Steril. 2005; 84: $945-50$. 